\title{
Nutritional Supplements and Neuroprotective Diets and Their Potential Clinical Significance in Post-Stroke Rehabilitation
}

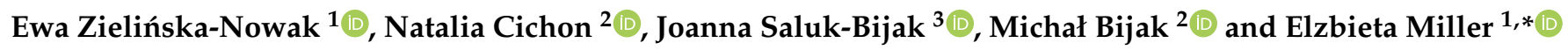 \\ 1 Department of Neurological Rehabilitation, Medical University of Lodz, Milionowa 14, 93-113 Lodz, Poland; \\ ewa.zielinska@umed.lodz.pl \\ 2 Biohazard Prevention Center, Faculty of Biology and Environmental Protection, University of Lodz, \\ Pomorska 141/143, 90-236 Lodz, Poland; natalia.cichon@biol.uni.lodz.pl (N.C.); \\ michal.bijak@biol.uni.lodz.pl (M.B.) \\ 3 Department of General Biochemistry, Faculty of Biology and Environmental Protection, University of Lodz, \\ Pomorska 141/143, 90-236 Lodz, Poland; joanna.saluk@biol.uni.lodz.pl \\ * Correspondence: elzbieta.dorota.miller@umed.lodz.pl; Tel.:+48-(0)42-6667-7461; Fax:+48-(0)42-6761-785
}

check for updates

Citation: Zielińska-Nowak, E.; Cichon, N.; Saluk-Bijak, J.; Bijak, M.; Miller, E. Nutritional Supplements and Neuroprotective Diets and Their Potential Clinical Significance in Post-Stroke Rehabilitation. Nutrients 2021, 13, 2704. https://doi.org/ $10.3390 /$ nu13082704

Academic Editors: Ligia

J. Dominguez and Giuseppe Salemi

Received: 29 June 2021

Accepted: 3 August 2021

Published: 5 August 2021

Publisher's Note: MDPI stays neutral with regard to jurisdictional claims in published maps and institutional affiliations.

Copyright: (c) 2021 by the authors. Licensee MDPI, Basel, Switzerland. This article is an open access article distributed under the terms and conditions of the Creative Commons Attribution (CC BY) license (https:// creativecommons.org/licenses/by/ $4.0 /)$.

\begin{abstract}
Nutrition and rehabilitation are crucial in post-stroke recovery, especially in the elderly. Since stroke is the leading cause of long-term disability, there is a need to promote special, individually tailored nutrition strategies targeting older patients with low motor ability. Chronic stroke survivors have higher risk of developing nutrition-related chronic diseases, such as sarcopenia, anemia, type 2 diabetes mellitus and osteoporosis. Moreover, reduced motor activity, cognitive impairment and depression might be aggravated by poor malnutrition status. Accumulated data suggest that nutritional supplements and neuroprotective diets can be associated with better effectiveness of post-stroke rehabilitation as well as brain recovery. Therefore, this review focuses on preventive strategies that can improve dietary intake and change dietary patterns. We highlight the importance of neuroprotective diets, the problem of dysphagia and the role of nutrition in rehabilitation. This article focuses on potential nutritional supplements and neuroprotective diets that may have an impact on functional recovery during and after rehabilitation. Moreover, a new approach to poststroke neuroplasticity including the use of agents from marine sources such as fucoxanthin and tramiprosate as compounds that might be used as potential neuroprotectants with antioxidative and anti-inflammatory properties is introduced.
\end{abstract}

Keywords: nutritional supplements; malnutrition; neuroprotective diets; stroke; rehabilitation

\section{Introduction}

Stroke is one of the most common causes of disability in adults. Currently, despite introducing thrombolysis and thrombectomy treatment, there is still high demand to prevent neuronal death and neurological dysfunction in post-stroke patients. Moreover, patients after stroke have about a $43 \%$ higher risk of stroke reoccurrence over 10 years with an increased annual rate of $4 \%$ [1].

Therefore, long-term management of risk factors, including proper nutrition, plays a major role in medical care, especially during the rehabilitation process. Prevention of stroke recurrence is mainly based on changes in behavioral strategies and lifestyle factors. The main lifestyle modifiable factors are smoking, diet, obesity, alcohol and physical activity [2].

Generally, effective rehabilitation requires a holistic approach. In most cases, poststroke rehabilitation begins the day after stroke, but it is a very short program due to the diagnostic and therapeutic process. The intensity of rehabilitation is tailored to patients' individual needs. However, during the first 2-3 months, when neuroplasticity is very active, the level of patients' activity is gradually accelerated and focused on functional, cognitive and emotional improvement [3]. 
Most patients are able to tolerate an increased duration of rehabilitation programs, especially in specialized post-stroke rehabilitation services or units. In different countries, there are different recommendations for the duration of the rehabilitation program [4].

In Poland, the minimum duration of the whole program including physiotherapy, cognition and speech therapy is 150 min daily with a one-day break on Sunday.

One of the most important factors determining post-stroke rehabilitation effectiveness is appropriate nutrition, adjusted to patient's medical history and increased demands during the complex biochemical processes of brain recovery and high physical and cognitive activity. Moreover, malnutrition is associated with poor clinical and functional outcomes in post-stroke patients, with greater incidence of infections and pressure sores as well as higher lengths of hospitalizations [5]. There are huge differences between reports in the prevalence of malnutrition in patients after a stroke, ranging from 6.1 to even $62 \%$, whilst other studies have reported the rate ranges from 8 to $49 \%$. Routine tests of nutritional status are recommended for all post-stroke patients in order to enhance their potential for recovery and prevent the development of malnutrition during rehabilitation [6,7].

The aim of this review is to present risk factors for the development of malnutrition and nutrition-related chronic diseases in post-stroke patients (Figure 1); the role of nutrition; and the most effective strategies to prevent malnutrition, including neuroprotective diets and nutritional supplements, in post-stroke rehabilitation. This article focuses on evidence that nutritional status has a correlation with functional recovery during and after rehabilitation. Moreover, a new approach to post-stroke neuroplasticity including treatment with agents from marine sources such as fucoxanthin and tramiprosate as compounds that might be used as potential neuroprotectants with antioxidative and anti-inflammatory properties is introduced.

\section{Risk factors, stroke symptoms and consequences of malnutrition in post-stroke rehabilitation process.}

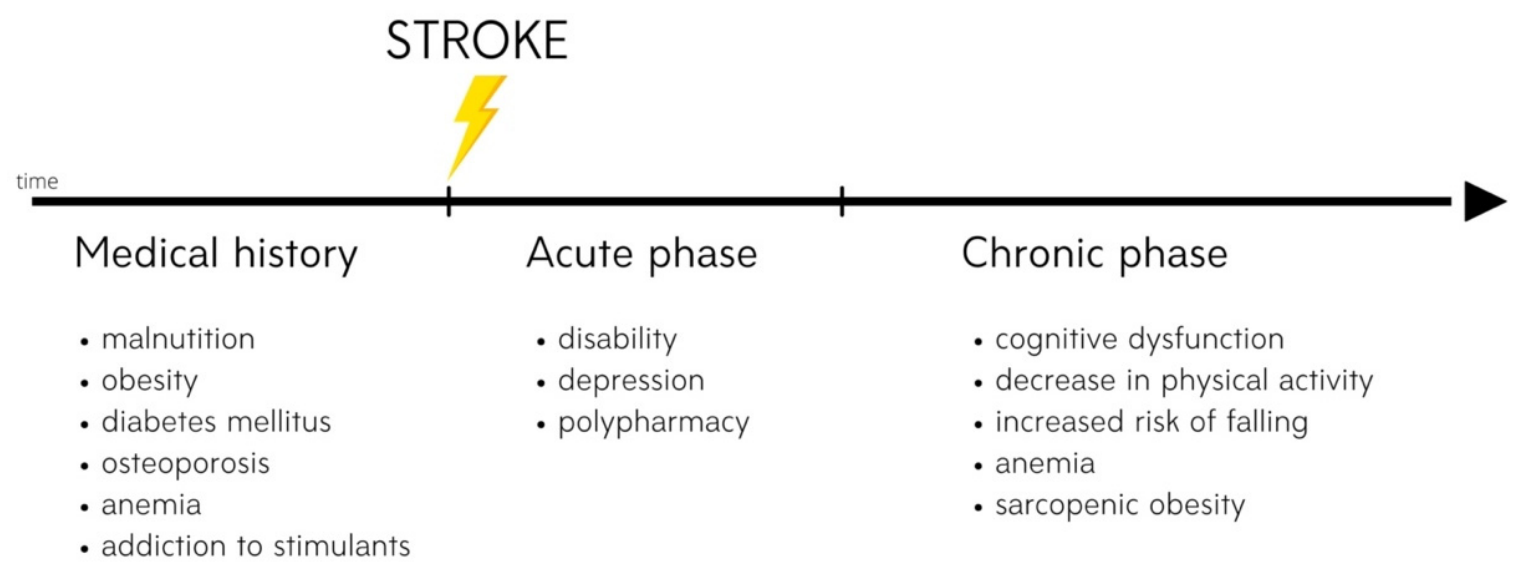

Figure 1. Risk factors, stroke symptoms and consequences of malnutrition in the post-stroke rehabilitation process.

Currently, there is great interest in dietary supplementation to support rehabilitation, alleviate vascular diseases, decrease ischemic brain damage and enhance processes of spontaneous recovery and neuroplasticity. Data from several clinical studies show medical benefits from dietary supplementation not only in functional but also in cognitive and emotional status in post-stroke patients. 


\section{Risk of Malnutrition after Stroke}

Malnutrition is common in patients with neurological conditions, including stroke. The causes of this abnormality are directly related to neurological diseases, such as cognitive functions and disorder of consciousness, neurogenic vomiting, neurogenic dysphagia, depression, motor deficit and gastrointestinal dysfunction [8-10].

A significant element of therapeutic and preventive management in central nervous system (CNS) disorders is proper assessment and monitoring of the nutritional status. The reasons for the reduced consumption of nutrients include dysphagia, obstruction or stricture of the esophagus, disability, a general deterioration in condition, increased catabolic processes, digestive disorders and pharmacotherapy [11].

Malnutrition is a well-documented negative prognostic factor both in the general population and in various patient groups. It greatly increases the risk of complications such as pressure ulcers and infections (especially of the respiratory system), electrolyte disturbances, coagulation disorders, anemia, osteoporosis and bradycardia and also reduces the quality of life. Furthermore, it influences the hospitalization time and the number of stays in intensive care units and reduces the effectiveness of rehabilitation [10]. Besides, malnutrition also increases mortality from roughly 30 to 180 days after the ischemic incident. In the Feed Or Ordinary Diet (FOOD) clinical trial it was noted that the odds ratio (OR) of death in the group of post-stroke patients with malnutrition was 2.32 (95\% confidence interval (CI) 1.78-3.02) compared to post-stroke patients with normal nutritional status [12].

The most important neurological cause of nutritional disorders is dysphagia, which includes disturbances in the swallowing process at any of its stages: from taking food into the mouth, through keeping it in the buccal cavity, chewing and shaping it, to transporting it from the oral cavity through the throat and esophagus to the stomach. The prevalence of dysphagia in the general population is estimated at $7 \%$; this percentage increases with age, and in the elderly, it reaches 50\% [13-15]. In patients with CNS disease, the most common cause of dysphagia, the prevalence of dysphagia is estimated to be $50 \%[16,17]$.

Neurogenic dysphagia can be caused by disturbances in the coordination of individual swallowing phases, paresis of the muscles involved in the act of swallowing, abnormal muscle tone, disturbance in swallowing-breathing coordination, disturbance of sensation in the mouth or throat, involuntary movements, disturbances in the central control of swallowing or most commonly a combination of these symptoms [18-20]. Neurogenic dysphagia is most often associated with neurological deficits that make it difficult to adopt and maintain a proper position while eating and can significantly reduce the critical insight into the symptoms presented. Patients with swallowing disorders also often have sensory disorders, undergo pharmacotherapy that can reduce muscle tone and attention and have problems with dentition. Importantly, a major impediment in the diagnosis of dysphagia is the frequent lack of patients' consciousness of the problem, which indicates the need for routine assessment of possible swallowing disorders by medical and nursing staff $[14-16,19]$.

The most important potentially fatal consequences of dysphagia, regardless of etiology, include dehydration, malnutrition and aspiration to the respiratory system, leading to Mendelson's syndrome [21,22]. For this reason, early diagnosis of dysphagia and proper nutritional intervention are of key importance for the prognosis of patients with CNS diseases. In all patients with dysphagia, it is extremely important to assess and monitor the nutritional status, including qualitative and quantitative evaluation of consumed food and fluid. This is extremely important because it enables the early identification of patients requiring nutritional support or treatment. In addition, careful oral hygiene, the use of antireflux procedures and safe feeding reduce the risk of pneumonia. Hospitalized patients requiring diet modification should have access to properly modified food and fluids [23]. 


\section{Nutrition-Related Chronic Diseases in Post-Stroke Patients}

\subsection{Osteoporosis}

Loss of bone mineral density (BMD) is a common symptom in post-stroke patients. Bone loss begins immediately after stroke and progresses for the first few months. Then, it stabilizes at a lower rate but still does not recede for at least a year [24]. The pathology of post-stroke osteoporosis is complex, as it may involve reduced bone load, reduced mobility, paresis and changes in muscle mass and strength. However, it may also be related to nutritional deficits [24,25]. Long-term hypocalcemia might also contribute to osteoporotic problems. In a recent study by Siotto et al. on calcium levels in post-stroke patients, it was discovered that $26.7 \%$ of patients had total calcium levels below the reference range, and it was suggested that serum calcium levels might be correlated with patients outcomes during the rehabilitation program. What is more, total protein and albumin were below the reference range in about $77 \%$ and $67 \%$ of patients. Authors recommend measurements of calcium levels at the beginning and during the rehabilitation program in order to apply appropriate supplementation or dietary program [26]. Osteoporosis not only negatively influences functional recovery, but also is associated with poor cognitive function during the acute and recovery stroke phases [27]. In addition to medications, treatment should also include muscle-strengthening training; resistance training; and appropriate supplementation, which includes vitamin D, folic acid, mecobalamin and calcium $[24,25]$. It is worth mentioning that only $15.5 \%$ of stroke patients receive treatment to prevent bone loss and that pharmacological treatment often prescribed after stroke, such as statins or warfarin, might have a negative influence on bone density [28].

\subsection{Anemia}

Anemia might be considered as one of the stroke risk factors. In post-stroke patients, it is a predictor of poor outcomes with increased morbidity and mortality $[29,30]$. Patients with this condition are more likely to have recurrent stroke [31]. In case of anemia, administration of iron is recommended, although excessive iron supplementation might cause side effects. If oral administration of iron is insufficient, it is worth considering the newer intravenous iron complexes (i.e., iron sucrose complexes), which are safer and easily administered $[29,32]$. In post-stroke patients, anemia should be treated as soon as possible due to the fact that hemoglobin improvement has a positive influence on functional recovery and may reduce the duration of hospitalization [33,34]. When comparing FIM scores between post-stroke patients with and without anemia, the nonanemic group had a significantly higher FIM score improvement and FIM efficiency [33].

\subsection{Sarcopenia}

Sarcopenia is also a frequent occurrence after stroke with an increased incidence of 14 to $54 \%$ [35]. Risk factors for sarcopenia include older age, lack of physical activity and malnutrition, which largely affect patients after stroke. Changes in muscle tissue begin within hours after stroke, and reduction in muscle mass is rapid, which can lead to physical function reduction or even disability [36]. Several factors contribute to sarcopenia occurrence; therefore, it requires an interdisciplinary approach, combining proper rehabilitation and nutritional support. The rehabilitation program should primarily consist of resistance training, but also walking and ADL training, paralyzed limb facilitation and aerobic training to prevent sarcopenic obesity [37]. When it comes to nutrition, studies suggest increased protein intake, high-energy and high-protein meals and leucine-enriched amino acid supplementation [37-39].

\subsection{Diabetes Mellitus}

Diabetes mellitus (DM) is another factor predicting poor outcome with higher mortality after stroke [40-42]. In an interesting study by Zhang Y. et al. it was suggested that patients with DM are more likely to suffer from late-onset post-stroke depression [43]. The prevalence of DM is significant; it has been determined that one-third of post-stroke 
patients have this disease [42]. Both the prevention of stroke among DM patients and poststroke treatment should primarily include normalizing blood glucose levels [41]. Lifestyle changes such as controlling body weight, minimizing total fat intake (especially saturated fat), consuming a low-carbohydrate diet, consuming low sodium and cholesterol and augmenting fiber intake may also be beneficial $[41,44]$.

\section{Preventive Strategies}

The serious socioeconomic problem of stroke requires the search for new neuroprotective management, both to reduce the number of new cases and to reduce the size of the stroke infarct and its consequences. The provision of neuroprotective compounds is therefore essential not only in the primary prevention of stroke, but also in post-stroke recovery.

\section{Neuroprotective Diets}

Currently, relationships between nutritional status, diet and the functioning of the central nervous system are increasingly recognized. The analysis of the literature shows the effect of individual nutrients from food on the nervous system, while multiannual population studies on eating behaviors and habits indicate the protective effect of the diet. It has been shown that certain types of diets have an effect on life expectancy, mortality, risk of cardiovascular disease and cognitive impairment. Diet as a potentially modifiable lifestyle element has a potential for primary and secondary prevention of risk factors for various diseases, including stroke. Both qualitative (minerals, vitamins, fats and proteins) and quantitative (number of calories consumed) aspects of the diet are considered.

Taking into account the relationship between the consumed food and the health condition, it was noticed that individual groups of products or individual behaviors affect not so much health, but the overall model of nutrition. The Mediterranean diet (MD) is one such model, characterized by food diversity; low calories; high consumption of fruit and vegetables, legumes, nuts and seeds, grains and fish; and relatively low consumption of meat and dairy. A meta-analysis by Papadaki et al. found that regular use of the $\mathrm{MD}$ reduced the risk of stroke (relative risk $(\mathrm{RR})=0.67,95 \%$ confidence interval $(\mathrm{CI})$ 0.35-0.98; I2 = 0\%) [45], and a meta-analysis, published in the Cochrane Library, assessing both the effect of the MD and the quality of clinical trials showed that the MD reduced the number of strokes in primary prevention (hazard risk (HR) $0.60,95 \%$ CI $0.45-0.80$; moderate-quality evidence). Low-quality evidence was also observed for a reduction in death and overall mortality from cardiovascular disease in secondary prevention (HR 1.0, 95\% CI 0.81-1.24; HR 0.81, 95\% CI 0.50-1.32, respectively). Moreover, the impact of the MD on the improvement of risk factors in primary prevention was demonstrated: reduction in triglycerides $(-0.09 \mathrm{mmol} / \mathrm{L}, 95 \% \mathrm{CI}-0.16$ to 0.01$)$, LDL cholesterol $(-0.15 \mathrm{mmol} / \mathrm{L}$, $95 \% \mathrm{CI}-0.27$ to -0.02 ; moderate-quality evidence) and diastolic $(-2.0 \mathrm{mmHg}, 95 \% \mathrm{CI}$ -2.29 to -1.71$)$ and systolic blood pressure $(-2.99 \mathrm{mmHg}, 95 \% \mathrm{CI}-3.45$ to -2.53$)$ [46]. The beneficial effect of the MD is probably related to synergistic interactions between the various ingredients as a whole of the nutritional regimen [47]. A potential mechanism underlying the effect of the MD on the vascular system may be associated with a beneficial impact on endothelium-dependent vasoreactivity and insulin resistance [48-50], as well as with antioxidant and anti-inflammatory activity [51-53].

The Mediterranean-DASH Intervention for Neurodegenerative Delay (MIND) diet is a hybrid of the Mediterranean diet and the Dietary Approaches to Stop Hypertension (DASH) diet, most often used in hypertension cardio- and cerebrovascular diseases. In 2015, Morris et al. presented a nutritional model that aimed to improve the functioning of the brain and nervous system, in particular cognitive functions, as well as reduce the risk of developing and progressing neurodegenerative diseases [54]. Based on large cohort studies, they found that consumption of at least six portions per week of green leafy vegetables (lettuce, cabbage, kale, and spinach), as well as berry fruits (strawberries, blueberries), significantly improved cognitive function. The effectiveness of the MIND diet has been confirmed in several cohort studies, which showed improvement of cognitive functions, 
including episodic, working and semantic memories; perceptual speed; and visuospatial ability [54-56]. In 2019, Cherian et al. conducted a study in which they assessed the effectiveness of the MIND diet in preventing post-stroke cognitive decline. One hundred six patients were enrolled; they were followed on average for 5.9 years. Cognitive functions were measured in five domains (semantic, episodic and working memories; perceptual orientation; and speed) using annual structured clinical estimation. They showed that after adjusting for sex, age, education, late-life cognitive activity, APOE- $\varepsilon 4$, caloric intake, smoking and physical activity, the highest and lowest terciles of MIND diets had a lower rate of global cognitive decline ( $\beta 0.08,95 \%$ CI $0.1-0.15)$ and lower decline in semantic memory ( $\beta 0.07,95 \%$ CI: $0.00,0.14)$ and perceptual speed ( $\beta 0.07,95 \%$ CI: $0.00,0.14)$ [57].

The prohealth properties of olive oil are associated with not only its content of over 30 types of phenolic compounds, but also the presence of MUFAs, mainly oleic acid and omega- 6 and omega-3 PUFAs. The effect of olive oil consumption in primary prevention of stroke is assessed by measuring the level of oleic acid in the plasma. The Three-City Study found that consuming a lot of olive oil, compared with minimal or no consumption, decreased the risk of stroke by approximately $73 \%(95 \%$ CI $10-92 \%, p=0.03)$, and the olive-oil-consuming subjects had lower plasma triglyceride concentration and body mass index (BMI) [58]. Similarly, meta-analyses evaluating the relationship between olive oil consumption in primary prevention suggested a neuroprotective effect in relation to vascular diseases [59,60]. Moreover, studies in animal models showed that olive oil reduced neuronal apoptosis, infarct volume, blood-brain barrier (BBB) permeability and brain edema and improved neurological deficits in rodents with I/R injury [61-63].

One variation of neuroprotective diet is the ketogenic diet (KD), which is of increasing interest with respect to various diseases of the nervous system. The main assumption of KD is the use of fatty acids as the main source of cellular energy; therefore, it is characterized by a high fat content (about $80-90 \%$ ), the maximum elimination of carbohydrates and less than $30 \%$ protein. KD causes an increased production of ketone bodies: acetoacetate $(\mathrm{AcC}), \beta$-hydroxybutyrate $(\mathrm{BHB})$ and acetone, alternative sources of cellular energy to glucose [64]. KD is widely used in the nonpharmacological treatment of epilepsy. The antiseizure effect of KD on the molecular level may be associated with ATP-sensitive potassium $\left(\mathrm{K}_{\mathrm{ATP}}\right)$ channels, BCL-2-associated agonists of cell death, vesicular glutamate transporters, lactate dehydrogenase and adenosine $A_{1}$ receptors $\left(A_{1} R s\right)$ [65]. However, in recent years, it has been suggested that the use of KD may have therapeutic potential in the treatment of neurodegenerative diseases, ischemia and traumatic brain injury. The mechanism of stroke-induced nerve tissue injury is mainly related to excitotoxicity, intracellular calcium load, production of reactive oxygen species, inflammation, apoptosis and mitochondrial dysfunction. Thus, the pathomechanism of I/R injury is to some extent common in neurodegenerative diseases. Currently, only studies in animal models showing the neuroprotective effects of ketones after stroke are available. They exhibit neurorestorative activity by reducing markers of apoptosis, inhibiting caspase 3 , as well as reactive oxygen species production [66]. Maalouf et al. observed that inhibition of mitochondrial reactive oxygen species (ROS) generation by ketones was associated with increased nicotinamide adenine dinucleotide (NADH) oxidation in the electron transport chain [67]. The antioxidant effect of ketones is related to the improvement of mitochondrial antioxidant capacity with a simultaneous increase in the level of glutathione [68]. Furthermore, Julio-Amilpas et al. confirmed that BHB has a protective effect on cortical neurons by inhibiting the production of ROS and increasing the production of adenosine triphosphate (ATP) [69]. Moreover, studies conducted by Suzuki et al. showed that BHB reduced brain edema and prolonged survival time by improving energy metabolism in an animal model [70], as well as reducing stroke area and neurological deficits in animals [71]. In turn, Yang et al. found that KD caused an increase in regional blood flow in the brain, a decrease in the volume of a stroke and an enhancement in the extracellular level of adenosine. The proposed mechanism is related to the activation of adenosine A1 receptor (A1R), causing phosphorylation of protein kinase B (Akt) and extracellular signal-regulated kinase 1/2 (ERK1/2), and to 
the upregulation of hypoxia-inducible factors (HIFs) and HIF-regulated genes (EPO and VEGF) [72]. Moreover, Shaafi et al. suggested that KD improved early behavioral and motor outcomes in rats with induced stroke [73].

\section{The Role of Nutritional Status in Post-Stroke Rehabilitation}

Rehabilitation plays a crucial role in post-stroke recovery. It not only can affect physical functioning, but also has a positive effect on psychosocial well-being. A proper exercise program can positively influence patients' mobility, balance, gait, muscle strength, pain, cognition, memory and, in general, quality of life [74]. Taking this into consideration, post-stroke care requires a multidisciplinary approach, including adequate nutrition, in order to provide patients with ideal conditions for rehabilitation.

There is some evidence that nutritional status is correlated with functional recovery during and after rehabilitation. The elderly, including those after stroke, often experience malnutrition, nutritional deficits or dehydration which also have a negative impact on their physical functioning, strength and independence in activities of daily living (ADL) [75]. Patients with higher Geriatric Nutritional Risk Index (GNRI) at admission have lower improvements in Functional Independence Measure (FIM), which suggests that GNRI may predict FIM gain during hospitalization [76].

In a study on 178 post-stroke patients with malnutrition, there was an association between improvement in nutritional status and ADL. Measurements were performed at the beginning and at the end of the rehabilitation program and were taken with FIM. The factor that was most likely related to the improvements in ADL was the maintenance of body weight. This study has also shown that patients who at the end of the rehabilitation program were still malnourished also had worse rehabilitation results in comparison to patients with a greater nutritional improvement during rehabilitation [77].

A recent study conducted in Japan assessed the impact of frequent individualized diet support during a rehabilitation program on patient outcomes. Four hundred fiftyfour patients underwent rehabilitation treatment, consisting of paralyzed limb facilitation, range-of-motion exercises, basic movement training, walking training, resistance training and aerobic exercises using an ergometer, aimed at improving endurance and weight loss to combat obesity, ADL training and dysphagia rehabilitation. Nutritional management was preceded by a thorough nutritional screening and assessment, and then provision of high-energy and high-protein meals for malnourished patients, calorie restriction for weight reduction and provision of adequate protein for maintaining muscle mass in obese patients were applied. Rehabilitation outcomes were measured with FIM, and it was found that frequent individualized diet support resulted in better functional recovery [78]. There has also been an interesting study in which the authors investigated the relationship between BMI and functional recovery after stroke in rehabilitation wards. It has shown that patients with obesity $\left(\geq 27.5 \mathrm{~kg} / \mathrm{m}^{2}\right)$ had significantly better results than other groups (underweight, standard, overweight) in FIM gain [79]. Similar results were obtained in a study on 819 patients in a post-stroke rehabilitation hospital. However, in that case, the overweight group had the highest FIM efficiency (FIM score changes per day), and the underweight group had the lowest FIM efficiency [80]. In Table 1 we summarize presented data concerning the correlation between nutritional status and functional recovery after stroke (Table 1). 
Table 1. The correlation between nutritional status and functional recovery.

\begin{tabular}{|c|c|c|c|c|c|c|c|}
\hline Study, Year, Reference & Study Design & Group 1 & Group 2 & Group 3 & Outcome Measures & \multicolumn{2}{|c|}{ Main Findings } \\
\hline Kokura et al., 2016 [76] & $\begin{array}{l}\text { Retrospective cohort study; } \\
n=540\end{array}$ & $\begin{array}{l}\text { High GNRI }<92 \\
n=480\end{array}$ & Low GNRI $\geq 92 ; n=60$ & - & FIM & $\begin{array}{l}1 \\
2\end{array}$ & $\begin{array}{l}\text { Patients with high nutritional-related } \\
\text { risk at admission had lower FIM gain. } \\
\text { High nutritional-related risk may } \\
\text { predict poor functional recovery. }\end{array}$ \\
\hline Nishioka et al., 2016 [77] & $\begin{array}{l}\text { cross-sectional study } \\
n=178\end{array}$ & $\begin{array}{l}\text { MNA-SF } \\
\text { NI }\end{array}$ & $\begin{array}{l}\text { MNA-SF } \\
\text { LI }\end{array}$ & $\begin{array}{l}\text { MNA-SF } \\
\text { GI }\end{array}$ & FIM & 2. & $\begin{array}{l}\text { FIM efficiency was significantly higher } \\
\text { in the GI group compared with the LI } \\
\text { and NI groups. } \\
\text { FIM gain was significantly lower in } \\
\text { the NI group compared with LI } \\
\text { and GI. } \\
\text { The GI group had a significantly } \\
\text { higher rate of home discharge. }\end{array}$ \\
\hline Shimazu et al., 2021 [78] & $\begin{array}{l}\text { single-left prospective } \\
\text { cohort study; } \\
n=454\end{array}$ & $\begin{array}{l}\text { low-frequency dietary } \\
\text { prescription }\end{array}$ & $\begin{array}{l}\text { high- frequency dietary } \\
\text { prescription }\end{array}$ & - & FIM & & $\begin{array}{l}\text { nts in the high-frequency group had } \\
\text { r FIM-motor scores at discharge but } \\
\text { er FIM-motor gains than } \\
\text { requency group. }\end{array}$ \\
\hline Rabadi et al., 2008 [81] & Clinical trial, $n=116$ & $\begin{array}{l}\text { intensive nutritional } \\
\text { supplementation }\end{array}$ & $\begin{array}{l}\text { standard nutritional } \\
\text { supplementation }\end{array}$ & - & $\begin{array}{l}\text { FIM, } \\
\text { 2-minute and } \\
\text { 6-minute timed walk tests }\end{array}$ & & $\begin{array}{l}\text { sive nutritional supplementation group } \\
\text { oved more than standard nutritional } \\
\text { lementation group in motor function. }\end{array}$ \\
\hline
\end{tabular}

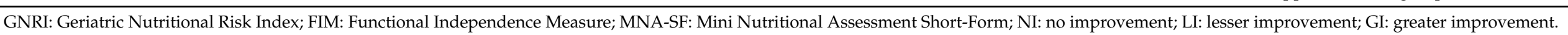




\section{Impact of Nutritional Supplementation on Post-Stroke Rehabilitation}

Nutritional supplements are recommended in patients who are undergoing rehabilitation very often due to the higher demand for bioactive compounds during complex processes of recovery.

In a randomized, prospective, double-blind, single-center study on 116 post-stroke, undernourished patients during rehabilitation, a group with intensive supplementation achieved better results than the group with standard supplementation. The outcomes that improved more included total FIM score, FIM motor subscore and 2 min and 6 min timed walk tests [81].

\subsection{Amino Acid Supplementation}

Amino acid supplementation seems to be a very important factor in the prevention of muscle protein hypercatabolism that often occurs after stroke. Rehabilitation in combination with amino acid supplementation can contribute to the improvement of muscle mass and functional efficiency in the early post-stroke phase [82]. Patients without essential amino acid supplementation continued to lose muscle mass even 76 days after stroke [83].

In order to increase muscle protein synthesis and reduce muscle soreness, post-exercise consumption of leucine-enriched amino acids is recommended because leucine plays a crucial role in triggering postprandial muscle protein synthesis through the mammalian target of rapamycin (mTOR) pathway [38]. Specific supplementation with leucine-enriched amino acids has proven to be effective in post-stroke patients with sarcopenia. In a randomized controlled trial, patients with sarcopenia were divided into two groups, both of which performed low-intensity resistance training during a rehabilitation program (8 weeks), but only the intervention group was supplemented with leucine-enriched amino acids ( $3 \mathrm{~g}$ of leucine $40 \%$ enriched essential amino acids and $9.7 \mathrm{~g}$ of carbohydrate). The improvement in FIM score was present in both groups, as was the improvement in skeletal muscle mass index (SMI) and handgrip strength, although the improvement in the intervention group was significantly greater than that in the control group [38]. Ikeda et al. investigated whether the timing of intake of supplemental branched-chain amino acids (BCAAs) had an effect on body composition and physical functioning. Supplements contained $3.5 \mathrm{~g}$ of amino acids, $6.5 \mathrm{~g}$ of protein and $40 \mathrm{IU}$ of vitamin D per $125 \mathrm{~mL}$. Patients were divided into two groups, depending on the timing of supplement intake: breakfast and post-exercise. Both groups underwent a rehabilitation program for 2 months, with two sessions daily. Muscle mass results were similar in both groups; however, BCAA intake with breakfast was more effective for physical performance and decreasing body fat mass [84].

\subsection{Vitamin D Supplementation}

Vitamin D deficiency is a common problem among stroke survivors, and it is associated with decreased muscle strength, balance and physical performance [85,86]. Although the results of studies on the effect of vitamin D supplementation on post-stroke rehabilitation are contradictory, most of them indicate its potential to support functions of the nervous system and enhance the rehabilitation process. Siotto et al. have drawn attention to an interesting issue: not only does serum concentration of vitamin D may affect post-stroke recovery during rehabilitation, but also single nucleotide polymorphisms and promoter methylation in genes that affect circulating vitamin levels may influence patients' outcomes. According to the authors, it is crucial to measure levels of $25(\mathrm{OH}) \mathrm{D}$ and determine the presence or absence of CYP2R1, CYP27B1, CYP4A1 and VDR polymorphisms and analyze their methylation before and after the rehabilitation program [87].

Most recent evidence suggests that vitamin D supplementation may positively affect lower extremity motor functioning and ambulation. Utkan Karasu et al. divided 76 patients into two groups, where the treatment group received 50,000 IU of vitamin D weekly for 4-12 weeks and the control group did not receive any vitamin D supplementation during rehabilitation. After rehabilitation, program patients receiving vitamin D had 
higher changes in scores of Brunnstrom recovery staging (lower extremity) and functional ambulation classification (FAC) $(p=0.005$ and $p=0.018)$ [88]. This is consistent with what has been previously found by Gupta et al., who found that post-stroke patients supplemented with vitamin D (600,000 IU single intramuscular injection and 60,000 IU once a month) plus elemental calcium (one gram per day) for 6 months had better results in modified Rankin scale than the control group receiving only usual care [86]. The effect of vitamin D supplementation (300,000 IU injection vs. saline injection in control group) on rehabilitation outcomes and balance in hemiplegic post-stroke patients has also been investigated. Patients were tested with Brunnstrom recovery staging (BRS), functional ambulation classification (FAC), modified Barthel index and Berg balance scale (BBS) at the beginning and at the end of the three-month rehabilitation program, and the outcomes of the BBS and modified Barthel index were significantly different between the two groups. Improvements in the vitamin D supplementation group were higher; however, BRS and FAC results were not [85]. There is some evidence that vitamin D supplementation may not improve the rehabilitation process after stroke, although it might be related to the dose of vitamin D, which in the study of Momosaki et al. was smaller (2000 IU per day) than in previously cited results [89].

The presented research results regarding the influence of supplementation on functional recovery during post-stroke rehabilitation are summarized in Table 2 (Table 2).

Figure 2 summarizes preventive nutritional strategies in post-stroke patients presented in this review (Figure 2).

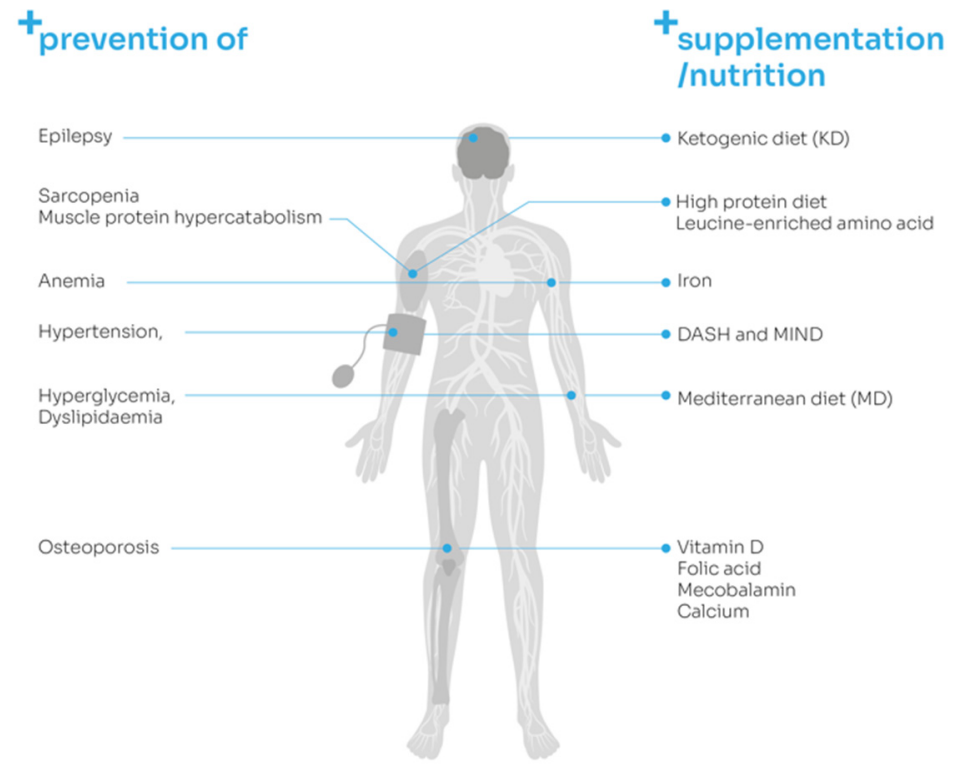

Figure 2. Potential preventive nutritional strategies in post-stroke patients. 
Table 2. The correlation between supplementation and functional recovery during rehabilitation.

\begin{tabular}{|c|c|c|c|c|c|}
\hline Study, Year, Reference & Study Design & Group 1 & Group 2 & Outcome Measures & Main Findings \\
\hline Yoshimura et al., 2019 [38] & $\begin{array}{l}\mathrm{RCT} \\
n=44\end{array}$ & $\begin{array}{l}\text { Supplement composition: } 3 \mathrm{~g} \text { of leucine } \\
40 \% \text { enriched essential amino acids and } \\
9.7 \mathrm{~g} \text { of carbohydrate }\end{array}$ & No supplementation & $\begin{array}{l}\text { FIM, } \\
\text { SMI, } \\
\text { handgrip strength }\end{array}$ & $\begin{array}{l}\uparrow \text { FIM score, significantly greater improvement in } \\
\text { the IG than in the CG }(p<0.045) \text {. } \\
\uparrow \text { handgrip strength, significantly greater } \\
\text { improvement in the IG }(p<0.01) \text {. } \\
\uparrow \text { SMI in the IG but not in the CG over time, } \\
\text { significantly greater improvement in the } \\
\text { intervention group. }\end{array}$ \\
\hline Ikeda T, et al., 2020 [84] & $\begin{array}{l}\mathrm{RCT} \\
n=69\end{array}$ & $\begin{array}{l}3.5 \mathrm{~g} \text { of amino acids, } 6.5 \mathrm{~g} \text { of protein and } \\
40 \mathrm{IU} \text { of vitamin D per } 125 \mathrm{~mL} \\
\text { at breakfast }\end{array}$ & $\begin{array}{l}3.5 \mathrm{~g} \text { of amino acids, } 6.5 \mathrm{~g} \text { of protein } \\
\text { and } 40 \mathrm{IU} \text { of vitamin } \mathrm{D} \text { per } 125 \mathrm{~mL} \\
\text { post-exercise }\end{array}$ & $\begin{array}{l}\text { skeletal muscle mass, lower limb } \\
\text { isometric strength, grip strength, } \\
\text { TUGT, } \\
\text { BBS, FIM }\end{array}$ & $\begin{array}{ll}\text { 1. } & \text { The effect of supplementation on muscle } \\
\text { mass was similar in both groups. } \\
\text { BC. } \\
\text { BCAA intake with breakfast and an exercise } \\
\text { program was effective at improving physical } \\
\text { performance and decreasing body fat mass. } \\
\text { 3. } \begin{array}{l}\text { Ingestion of BCAAs with breakfast is } \\
\text { effective for promoting rehabilitation of } \\
\text { post-stroke patients. }\end{array}\end{array}$ \\
\hline Utkan Karasu 2021 et al., [88] & $n=76$ & $\begin{array}{l}50,000 \text { IU of vitamin D weekly for } \\
4-12 \text { weeks }\end{array}$ & No supplementation & FAC, BRS lower extremity & $\begin{array}{l}\uparrow \text { changes in FAC and BRS scores in group } 1 \\
(p=0.005 \text { and } p=0.018) . \\
\uparrow \text { changes in FAC and BRS scores in patients who } \\
\text { were undergoing rehabilitation for the first time } \\
\text { and/or in the first } 3 \text { months after stroke in group } 1 \\
\text { than group } 2(p<0.05) \text {. } \\
\text { In patients }>3 \text { months after stroke, vitamin D } \\
\text { treatment did not affect FAC and BRS scores. }\end{array}$ \\
\hline Gupta et al., 2016 [86] & $\begin{array}{l}\mathrm{RCT} ; \\
n=73\end{array}$ & $\begin{array}{l}\text { Vitamin D ( } 600,000 \text { IU single } \\
\text { intramuscular injection and } 60,000 \mathrm{IU} \\
\text { once a month) + calcium (one gram per } \\
\text { day) for } 6 \text { months }\end{array}$ & No supplementation, only usual care & Modified Rankin scale & $\begin{array}{l}\text { Patients supplemented with vitamin } \mathrm{D} \text { and calcium } \\
\text { had better results in modified Rankin scale than } \\
\text { control group receiving only usual care. }\end{array}$ \\
\hline Sari et al., 2018 [85] & $\begin{array}{l}\text { RCT; } \\
n=132\end{array}$ & 300,000 IU vitamin D injection & saline intramuscular injection & BRS, FAS, MBI, BBS & $\begin{array}{l}\text { The BBS results and MBI scores significantly } \\
\text { differed between the two groups (higher scores in } \\
\text { vitamin D group), but BRS and FAS test results did } \\
\text { not significantly differ. }\end{array}$ \\
\hline Momosaki et al., 2019 [89] & $\begin{array}{l}\mathrm{RCT} \\
n=100\end{array}$ & $\begin{array}{l}\text { Vitamin D } \\
(2000 \text { IU } \\
\text { per day) } \\
8 \text { weeks }\end{array}$ & placebo & Barthel index & $\begin{array}{l}\text { The mean gain in the Barthel index score: } \\
19.0 \pm 14.8 \text { in group } 1 \text { and } 19.5 \pm 13.1 \text { in group } 2 \\
(p=0.88) \text {. The Barthel index efficiency was } \\
0.32 \pm 0.31 \text { in group } 1 \text { and } 0.28 \pm 0.21 \text { in group } 2 \\
(p=0.38) \text {. There was no significantly higher } \\
\text { improvement in rehabilitation outcomes in the } \\
\text { supplemented group. }\end{array}$ \\
\hline
\end{tabular}

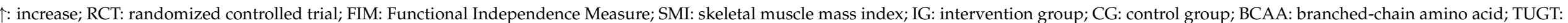

timed up-and-go test; BBS: Berg balance scale; BRS: Brunnstrom recovery staging; FAS: functional ambulation scale; MBI: modified Barthel index; FAC: functional ambulation classification. 


\section{Agents from Marine Sources-A New Approach to Post-Stroke Neuroplasticity}

Marine organisms are an excellent source of new chemicals, including a variety of primary and secondary metabolites with potent biological activity. Differences within species living in different marine environments may allow for compound variations and concentrations. Sea algae, whose metabolites have anti-inflammatory, antioxidant and antiamyloidogenic properties and affect cholesterol homeostasis, are worth noting in the context of their use as an adjuvant in the treatment of stroke. Thus, they have been shown to reduce neurotoxicity caused by glutamate, hydrogen peroxide and glucose or oxygen deficiency (Table 3) [90].

Fucoxanthin, contained in edible brown seaweed, decreased stroke volume, neurological deficits and the expression of proapoptotic proteins by activating the Nrf2/HO-1 pathway in the rat model of stroke [91]. In vitro studies have shown that fucoxanthin has an antioxidant effect by increasing the expression of superoxide dismutase and the production of glutathione, which was associated with the inhibition of $\mathrm{H}_{2} \mathrm{O}_{2}$-induced DNA damage [92]. Furthermore, fucoxanthin promoted cell survival through enhancement of BDNF bioavailability and activation of cAMP-dependent protein kinase (PKA)/cAMP response element-binding (CREB) pathway [98]. In animal models, fucoxanthin attenuated scopolamine-induced cognitive impairment, possibly by inhibiting acetylcholinesterase activity and modulating BDNF expression [94]. Moreover, it has been shown that this compound inhibits LPS-induced microglial neuroinflammation by reducing the secretion of inflammatory mediators-interleukin (IL) $1 \beta$, IL-6, tumor necrosis factor alpha (TNF- $\alpha$ ), nitric oxide (NO) and prostaglandin E2 (PGE2). The anti-inflammatory activity of fucoxanthin is manifested by attenuating the mitogen-activated protein kinase (MAPK)/activating protein-1 (AP-1) and protein kinase $\mathrm{B}(\mathrm{Akt}) / \mathrm{NF}-\mathrm{kB}$ pathways, as well as by lowering the expression of cyclooxygenase 2 (COX2) and inducible nitric oxide synthase (iNOS) [92,98].

Tramiprosate, found in red marine algae, decreased infarct volume in a dose-dependent manner in the rat stroke model. It was observed that tramiprosate at a dose of $50 \mathrm{mg} / \mathrm{kg}$ restored neurological deficits, and the time window was at least $6 \mathrm{~h}$. A potential neuroprotective mechanism of these phytochemicals may be related to NMDA receptor (NMDAR) inhibition and nNOS translocation from the cytosol to the membrane without impact on total nNOS expression [95].

In addition, phlorotannins, polyphenols contained in brown algae, are popular foods in East Asian countries due to their strong antioxidant and anti-inflammatory properties. It has been demonstrated that Ecklonia cava polyphenols (ECP) dose-dependently (10 and $50 \mathrm{mg} / \mathrm{kg}$ ) reduced brain edema and infarct volume and improved neurological dysfunction in the rat model of stroke. ECP inhibited neuronal apoptosis and promoted cell survival by inhibiting $\mathrm{Ca}^{2+}$-dependent neurotoxicity in a rat stroke model [96]. Similarly, ECP blocked the dose-dependent glutamate-mediated neuronal cytotoxicity $(1-50 \mathrm{mg} / \mathrm{kg})$. Moreover, ECP showed an antioxidant effect as evidenced by a reduction in mitochondrial $\mathrm{Ca}^{2+}$ overload and reactive oxygen species, increased mitochondrial membrane potential $\left(\Delta \Psi_{\mathrm{m}}\right)$ and increased expression of heme oxygenase (HO-1) through Nrf2 nuclear translocation [97]. 
Table 3. Neuroprotective action of compounds from marine sources.

\begin{tabular}{|c|c|c|c|c|c|}
\hline & Study, Year, Reference & $\begin{array}{l}\text { Study } \\
\text { Design }\end{array}$ & Supplementation & Outcome Measures & Main Findings \\
\hline \multirow{5}{*}{ 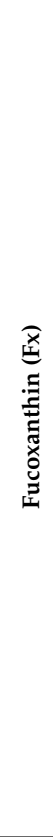 } & \multirow{2}{*}{ Hu et al., 2018 [91] } & MCAO rat & $\begin{array}{l}\text { Intragastrically administrated; } \\
30,60 \text { and } 90 \mathrm{mg} / \mathrm{kg} \mathrm{Fx} ; \\
1 \mathrm{~h} \text { before MCAO induction }\end{array}$ & $\begin{array}{l}\text { Infarct area; neurological function; } \\
\text { brain water content of rats }\end{array}$ & $\begin{array}{l}\text { Effect in dose-dependent manner } \\
\text { Improvement of the neurologic deficit } \\
\text { Decrease in the infarct volume } \\
\text { Reduction in the level of apoptosis-associated proteins in } \\
\text { brain tissues }\end{array}$ \\
\hline & & $\begin{array}{l}\text { In vitro study OGD/R model (rat } \\
\text { cortical neuron) }\end{array}$ & 5, 10 and $20 \mu \mathrm{M} \mathrm{Fx}$ & $\begin{array}{l}\text { Oxidative stress level; } \\
\text { apoptosis level }\end{array}$ & $\begin{array}{l}\text { Inhibition of increased caspase } 3 \text { expression } \\
\text { Decrease in Bcl-2/Bax ratio } \\
\text { Increase in SOD activity } \\
\text { Decrease in MDA level } \\
\text { Inhibition of OGD/R-induced apoptosis } \\
\text { Decrease in ROS accumulation }\end{array}$ \\
\hline & Pangestuti et al., 2013 [92] & $\begin{array}{l}\text { In vitro study (amyloid- } \beta 42 \text {-induced } \\
\text { BV2 microglia cells) }\end{array}$ & 5,10 and $50 \mu \mathrm{M} \mathrm{Fx}$ & $\begin{array}{l}\text { Level of oxidative stress and } \\
\text { inflammation }\end{array}$ & $\begin{array}{l}\text { Inhibition of phosphorylation of MAPK pathway } \\
\text { Inhibition of free radical-induced DNA oxidation } \\
\text { Decrease in intracellular ROS production } \\
\text { Increase in antioxidative enzymes activity }\end{array}$ \\
\hline & Zhou et al., 2017 [93] & In vitro study (BV-2 cells) & 5,10 and $20 \mu \mathrm{M} \mathrm{Fx}$ & $\begin{array}{l}\text { Anti-inflammatory, antioxidant and } \\
\text { neuroprotective effect }\end{array}$ & $\begin{array}{l}\text { Effect in dose-dependent manner } \\
\text { Inhibition of proinflammatory mediators, both protein and } \\
\text { mRNA expression: TNF- } \alpha \text {, IL-6, PGE2, ROS, NO and COX, iNOS } \\
\text { Inhibition of Akt/NF } \text { B and MAPK/AP-1 pathways } \\
\text { Promotion of BDNF production }\end{array}$ \\
\hline & Lin et al., 2016 [94] & $\begin{array}{l}\text { Institute of Cancer Research (ICR) } \\
\text { mice }\end{array}$ & $\begin{array}{l}\text { Six groups: } \\
\text { (1) } \quad \text { control } \\
\text { (2) } 3 \mathrm{mg} / \mathrm{kg} \text { scopolamine } \\
\text { (3) } 3 \mathrm{mg} / \mathrm{kg} \mathrm{scopolamine}+50 \mathrm{mg} / \mathrm{kg} \mathrm{Fx} \\
\text { (4) } 3 \mathrm{mg} / \mathrm{kg} \text { scopolamine }+100 \mathrm{mg} / \mathrm{kg} \mathrm{Fx} \\
\text { (5) } 3 \mathrm{mg} / \mathrm{kg} \text { scopolamine }+200 \mathrm{mg} / \mathrm{kg} \mathrm{Fx} \\
\text { (6) } 3 \mathrm{mg} / \mathrm{kg} \text { scopolamine }+3 \mathrm{mg} / \mathrm{kg} \text { donepezil }\end{array}$ & $\begin{array}{l}\text { Impact on scopolamine-induced } \\
\text { cognitive impairments; impact on } \\
\text { AChE activity; } \\
\text { further examined if fucoxanthin } \\
\text { could directly inhibit AChE in vitro }\end{array}$ & $\begin{array}{l}\text { Improved cognitive impairments } \\
\text { Decrease in AChE activity } \\
\text { Decrease in choline acetyltransferase activity and BDNF } \\
\text { expression } \\
\text { Inhibition of AChE with an } \mathrm{IC}_{50} \text { value of } 81.2 \mu \mathrm{M}\end{array}$ \\
\hline 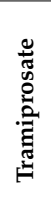 & Wu et al., 2014 [95] & MCAO rats & $50 \mathrm{mg} / \mathrm{kg}$ & $\begin{array}{l}\text { Neuroprotective effect and impact on } \\
\text { functional recovery }\end{array}$ & $\begin{array}{l}\text { Effect in dose-dependent manner } \\
\text { Reduction in the infarct volume } \\
\text { Therapeutic window- } 6 \mathrm{~h} \\
\text { Improvement of neurological status } \\
\text { Neuroprotective effect expressed by NMDAR } \\
\text { Decrease in nNOS/PSD95 association } \\
\text { Suppression of nNOS translocation to membrane }\end{array}$ \\
\hline
\end{tabular}


Table 3. Cont.

\begin{tabular}{|c|c|c|c|c|c|}
\hline & Study, Year, Reference & $\begin{array}{l}\text { Study } \\
\text { Design }\end{array}$ & Supplementation & Outcome Measures & Main Findings \\
\hline \multirow{3}{*}{ 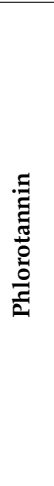 } & \multirow{2}{*}{ Kim et al., 2012 [96] } & MCAO rats & \multirow{2}{*}{$\begin{array}{l}\text { Ecklonia cava polyphenols at } 10 \mathrm{mg} / \mathrm{kg} \text { and } \\
50 \mathrm{mg} / \mathrm{kg} \text { intraperitoneally administrated }\end{array}$} & \multirow{2}{*}{ Neuroprotective effect } & $\begin{array}{l}\text { Effect in dose-dependent manner } \\
\text { Decrease in the extent of brain edema and infarct volume } \\
\text { Inhibition of apoptosis } \\
\text { Improvement of decreased neurological motor function }\end{array}$ \\
\hline & & $\begin{array}{l}\text { In vitro study (differentiated } \\
\text { neuroblastoma cell line SH-SY5Y) }\end{array}$ & & & $\begin{array}{l}\text { Improvement of cell viability } \\
\text { Decrease in } \mathrm{H}_{2} \mathrm{O}_{2} \text {-induced oxidative stress } \\
\text { Inhibition of increased cytosolic calcium } \\
\text { Reduction in calcium-induced neurotoxicity }\end{array}$ \\
\hline & Cui et al., 2019 [97] & $\begin{array}{l}\text { In vitro study (primary cortical } \\
\text { neurons } \\
\text { HT22 neurons) }\end{array}$ & $\begin{array}{l}100 \mu \mathrm{M}, 24 \mathrm{~h} \\
5 \mathrm{mM}, 12 \mathrm{~h}\end{array}$ & Neuroprotective effect & $\begin{array}{l}\text { Effect in dose-dependent manner } \\
\text { Enhancement of cell viability } \\
\text { Recovery of neurons' morphological deterioration } \\
\text { Suppression of intracellular ROS level, disruption of } \\
\text { mitochondrial membrane potential, overload of ROS and } \mathrm{Ca}^{2+} \text { in } \\
\text { mitochondria and ATP depletion } \\
\text { Inhibition of oxidative stress } \\
\text { Activation of Nrf2/HO-1 pathway }\end{array}$ \\
\hline
\end{tabular}




\section{Conclusions}

Nutritional interventions in post-stroke patients are a very important issue in patient care during the complex rehabilitation process, which includes functional training, occupational therapy, speech and cognitive therapy and physical medicine procedures. Post-stroke patients, especially the elderly, often suffer from nutrition-related diseases such as sarcopenia, osteoporosis, anemia and diabetes mellitus; therefore, there is a need to conduct nutritional interventions concomitant with rehabilitation. Future therapies, such as agents from marine sources, which are highly safe to consume, might be also included as potential neuroprotectants with antioxidative and anti-inflammatory properties. Therefore, the present narrative review highlights particular compounds that can be used in everyday clinical practice to improve patients' responses to the high demand of a multitasking rehabilitation program. However, most of the presented clinical studies were conducted using small groups of participants, with clinical scales where the score of patient symptoms is somewhat subjective and not so precise. Moreover, there is a huge problem with the assessment of nutritional status due to a lack of valid markers of malnutrition. There is a need for future multicenter studies, with long-term observations, to create nutritional recommendations for post-stroke care and rehabilitation.

Author Contributions: Conceptualization, E.Z.-N., N.C. and E.M.; methodology, E.M.; software, E.Z.-N.; validation, E.M. and J.S.-B.; formal analysis, M.B.; investigation, E.Z.-N. and N.C.; resources, E.Z.-N. and N.C.; data curation, E.M. and J.S.-B.; writing-original draft preparation, E.M., E.Z.-N. and N.C.; writing - review and editing, E.M., E.Z.-N. and N.C.; visualization, E.Z.-N.; supervision, E.M.; project administration, E.M.; funding acquisition, E.M. All authors have read and agreed to the published version of the manuscript.

Funding: This study was supported by grants from the Medical University of Lodz No. 503/6-12705/503-51-001-19.

Conflicts of Interest: The authors declare no conflict of interest.

\section{References}

1. Hardie, K.; Hankey, G.J.; Jamrozik, K.; Broadhurst, R.J.; Anderson, C. Ten-year risk of first recurrent stroke and disability after first-ever stroke in the Perth Community Stroke Study. Stroke 2004, 35, 731-735. [CrossRef]

2. Han, J.; Mao, W.; Ni, J.; Wu, Y.; Liu, J.; Bai, L.; Shi, M.; Tu, J.; Ning, X.; Wang, J. Rate and Determinants of Recurrence at 1 Year and 5 Years After Stroke in a Low-Income Population in Rural China. Front. Neurol. 2020, 11, 2. [CrossRef] [PubMed]

3. Ballester, B.R.; Maier, M.; Duff, A.; Cameirão, M.; Bermúdez, S.; Duarte, E.; Cuxart, A.; Rodríguez, S.; San Segundo Mozo, R.M.; Verschure, P.F.M.J. A critical time window for recovery extends beyond one-year post-stroke. J. Neurophysiol. 2019, 122, 350-357. [CrossRef]

4. Winstein, C.J.; Stein, J.; Arena, R.; Bates, B.; Cherney, L.R.; Cramer, S.C.; Deruyter, F.; Eng, J.J.; Fisher, B.; Harvey, R.L.; et al. Guidelines for Adult Stroke Rehabilitation and Recovery: A Guideline for Healthcare Professionals From the American Heart Association/American Stroke Association. Stroke 2016, 47, e98-e169. [CrossRef] [PubMed]

5. Foley, N.C.; Salter, K.L.; Robertson, J.; Teasell, R.W.; Woodbury, M.G. Which reported estimate of the prevalence of malnutrition after stroke is valid? Stroke 2009, 40, e66-e74. [CrossRef] [PubMed]

6. Shen, H.C.; Chen, H.F.; Peng, L.N.; Lin, M.H.; Chen, L.K.; Liang, C.K.; Lo, Y.K.; Hwang, S.J. Impact of nutritional status on long-term functional outcomes of post-acute stroke patients in Taiwan. Arch. Gerontol. Geriatr. 2011, 53, e149-e152. [CrossRef] [PubMed]

7. Sabbouh, T.; Torbey, M.T. Malnutrition in Stroke Patients: Risk Factors, Assessment, and Management. Neurocrit. Care 2018, 29, 374-384. [CrossRef]

8. Chauwa, L.; Appiah, C.A.; Nsiah, K.; Sarfo, F.S. Nutritional risk markers among stroke out-patients at the neurology clinic of a teaching hospital in Ghana. Pan Afr. Med. J. 2020, 37, 258. [CrossRef]

9. Mullins, N. Nutrition and hydration management among stroke patients in inpatient rehabilitation: A best practice implementation project. JBI Evid. Implement. 2021, 19, 56-67. [CrossRef]

10. Sato, Y.; Yoshimura, Y.; Abe, T. Nutrition in the First Week after Stroke Is Associated with Discharge to Home. Nutrients 2021, 13, 943. [CrossRef]

11. Chen, N.; Li, Y.; Fang, J.; Lu, Q.; He, L. Risk factors for malnutrition in stroke patients: A meta-analysis. Clin. Nutr. 2019, 38, 127-135. [CrossRef] [PubMed]

12. Dennis, M.S.; Lewis, S.C.; Warlow, C.; Collaboration, F.T. Routine oral nutritional supplementation for stroke patients in hospital (FOOD): A multicentre randomised controlled trial. Lancet 2005, 365, 755-763. [CrossRef] 
13. Bramanti, E.; Arcuri, C.; Cecchetti, F.; Cervino, G.; Nucera, R.; Cicciù, M. Dental management in dysphagia syndrome patients with previously acquired brain damages. Dent. Res. J. 2012, 9, 361-367.

14. Clavé, P.; Shaker, R. Dysphagia: Current reality and scope of the problem. Nat. Rev. Gastroenterol. Hepatol. 2015, 12, 259-270. [CrossRef]

15. Roden, D.F.; Altman, K.W. Causes of dysphagia among different age groups: A systematic review of the literature. Otolaryngol Clin. N. Am. 2013, 46, 965-987. [CrossRef]

16. Warnecke, T.; Labeit, B.; Schroeder, J.; Reckels, A.; Ahring, S.; Lapa, S.; Claus, I.; Muhle, P.; Suntrup-Krueger, S.; Dziewas, R. Neurogenic Dysphagia: Systematic Review and Proposal of a Classification System. Neurology 2021, 96, e876-e889. [CrossRef]

17. Lapa, S.; Foerch, C.; Singer, O.C.; Hattingen, E.; Luger, S. Ischemic Lesion Location Based on the ASPECT Score for Risk Assessment of Neurogenic Dysphagia. Dysphagia 2020. [CrossRef]

18. Singh, A.; Khatri, G.; Handa, K.K. Unusual cause of dysphagia and dysphonia. BMJ Case Rep. 2021, 14, e243060. [CrossRef]

19. Schumann-Werner, B.; Dogan, I.; Mirzazade, S.; Mall, B.; Overbeck, R.; Honrath, P.; Schulz, J.B.; Reetz, K.; Werner, C.J. Clinical predictors and neural correlates for compromised swallowing safety in Huntington's Disease. Eur. J. Neurol. 2021. [CrossRef]

20. Zeng, L.; Song, Y.; Dong, Y.; Wu, Q.; Zhang, L.; Yu, L.; Gao, L.; Shi, Y. Risk Score for Predicting Dysphagia in Patients After Neurosurgery: A Prospective Observational Trial. Front. Neurol. 2021, 12, 605687. [CrossRef]

21. Kazachkov, M.; Palma, J.A.; Norcliffe-Kaufmann, L.; Bar-Aluma, B.E.; Spalink, C.L.; Barnes, E.P.; Amoroso, N.E.; Balou, S.M.; Bess, S.; Chopra, A.; et al. Respiratory care in familial dysautonomia: Systematic review and expert consensus recommendations. Respir. Med. 2018, 141, 37-46. [CrossRef]

22. Alty, J.; Robson, J.; Duggan-Carter, P.; Jamieson, S. What to do when people with Parkinson's disease cannot take their usual oral medications. Pract. Neurol. 2016, 16, 122-128. [CrossRef]

23. Dziewas, R.; Allescher, H.D.; Aroyo, I.; Bartolome, G.; Beilenhoff, U.; Bohlender, J.; Breitbach-Snowdon, H.; Fheodoroff, K.; Glahn, J.; Heppner, H.J.; et al. Diagnosis and treatment of neurogenic dysphagia-S1 guideline of the German Society of Neurology. Neurol. Res. Pract. 2021, 3, 23. [CrossRef]

24. Yang, F.Z.; Jehu, D.A.M.; Ouyang, H.; Lam, F.M.H.; Pang, M.Y.C. The impact of stroke on bone properties and muscle-bone relationship: A systematic review and meta-analysis. Osteoporos. Int. 2020, 31, 211-224. [CrossRef]

25. Carda, S.; Cisari, C.; Invernizzi, M.; Bevilacqua, M. Osteoporosis after stroke: A review of the causes and potential treatments. Cerebrovasc. Dis. 2009, 28, 191-200. [CrossRef]

26. Siotto, M.; Germanotta, M.; Santoro, M.; Di Blasi, C.; Loreti, C.; Mastropaolo, S.; Aprile, I. Total Serum Calcium and Recovery after Rehabilitation in Patients with Stroke. Appl. Sci. 2020, 10, 7893. [CrossRef]

27. Lee, H.Y.; Park, J.H.; Lee, H.; Kim, T.W.; Yoo, S.D. Does Hip Bone Density Differ between Paretic and Non-Paretic Sides in Hemiplegic Stroke Patients? and Its Relationship with Physical Impairment. J. Bone Metab. 2020, 27, 237-246. [CrossRef] [PubMed]

28. Hsieh, C.Y.; Sung, S.F.; Huang, H.K. Drug treatment strategies for osteoporosis in stroke patients. Expert Opin. Pharm. 2020, 21, 811-821. [CrossRef]

29. Kaiafa, G.; Savopoulos, C.; Kanellos, I.; Mylonas, K.S.; Tsikalakis, G.; Tegos, T.; Kakaletsis, N.; Hatzitolios, A.I. Anemia and stroke: Where do we stand? Acta Neurol. Scand. 2017, 135, 596-602. [CrossRef]

30. Li, Z.; Zhou, T.; Li, Y.; Chen, P.; Chen, L. Anemia increases the mortality risk in patients with stroke: A meta-analysis of cohort studies. Sci. Rep. 2016, 6, 26636. [CrossRef]

31. Milionis, H.; Papavasileiou, V.; Eskandari, A.; D'Ambrogio-Remillard, S.; Ntaios, G.; Michel, P. Anemia on admission predicts short- and long-term outcomes in patients with acute ischemic stroke. Int. J. Stroke 2015, 10, 224-230. [CrossRef] [PubMed]

32. Bhavi, S.B.; Jaju, P.B. Intravenous iron sucrose $\mathrm{v} / \mathrm{s}$ oral ferrous fumarate for treatment of anemia in pregnancy. A randomized controlled trial. BMC Pregnancy Childbirth 2017, 17, 137. [CrossRef]

33. Chan, T.; Ganasekaran, G. The Effect of Anemia on the Functional Outcomes of the Stroke Patients and the Efficiency of their Stroke Rehabilitation. J. Stroke Cereb. Dis. 2015, 24, 1438-1442. [CrossRef] [PubMed]

34. Yoshimura, Y.; Wakabayashi, H.; Shiraishi, A.; Nagano, F.; Bise, T.; Shimazu, S. Hemoglobin Improvement is Positively Associated with Functional Outcomes in Stroke Patients with Anemia. J. Stroke Cereb. Dis. 2021, 30, 105453. [CrossRef]

35. Mas, M.F.; González, J.; Frontera, W.R. Stroke and sarcopenia. Curr. Phys. Med. Rehabil. Rep. 2020, 8, 452-460. [CrossRef]

36. Su, Y.; Yuki, M.; Otsuki, M. Prevalence of stroke-related sarcopenia: A systematic review and meta-analysis. J. Stroke Cereb. Dis. 2020, 29, 105092. [CrossRef] [PubMed]

37. Nagano, F.; Yoshimura, Y.; Bise, T.; Shimazu, S.; Shiraishi, A. Muscle mass gain is positively associated with functional recovery in patients with sarcopenia after stroke. J. Stroke Cereb. Dis. 2020, 29, 105017. [CrossRef]

38. Yoshimura, Y.; Bise, T.; Shimazu, S.; Tanoue, M.; Tomioka, Y.; Araki, M.; Nishino, T.; Kuzuhara, A.; Takatsuki, F. Effects of a leucine-enriched amino acid supplement on muscle mass, muscle strength, and physical function in post-stroke patients with sarcopenia: A randomized controlled trial. Nutrition 2019, 58, 1-6. [CrossRef]

39. Lathuilière, A.; Mareschal, J.; Graf, C.E. How to Prevent Loss of Muscle Mass and Strength among Older People in NeuroRehabilitation? Nutrients 2019, 11, 881. [CrossRef]

40. Hill, M.D. Stroke and diabetes mellitus. Handb. Clin. Neurol. 2014, 126, 167-174. [CrossRef]

41. Chen, R.; Ovbiagele, B.; Feng, W. Diabetes and Stroke: Epidemiology, Pathophysiology, Pharmaceuticals and Outcomes. Am. J. Med. Sci. 2016, 351, 380-386. [CrossRef] 
42. Lau, L.H.; Lew, J.; Borschmann, K.; Thijs, V.; Ekinci, E.I. Prevalence of diabetes and its effects on stroke outcomes: A meta-analysis and literature review. J. Diabetes Investig. 2019, 10, 780-792. [CrossRef] [PubMed]

43. Zhang, Y.; He, J.R.; Liang, H.B.; Lu, W.J.; Yang, G.Y.; Liu, J.R.; Zeng, L.L. Diabetes mellitus is associated with late-onset post-stroke depression. J. Affect. Disord. 2017, 221, 222-226. [CrossRef]

44. Gaillard, T.; Miller, E. Guidelines for Stroke Survivors with Diabetes Mellitus. Stroke 2018, 49, e215-e217. [CrossRef]

45. Papadaki, A.; Nolen-Doerr, E.; Mantzoros, C.S. The Effect of the Mediterranean Diet on Metabolic Health: A Systematic Review and Meta-Analysis of Controlled Trials in Adults. Nutrients 2020, 12, 3342. [CrossRef]

46. Rees, K.; Takeda, A.; Martin, N.; Ellis, L.; Wijesekara, D.; Vepa, A.; Das, A.; Hartley, L.; Stranges, S. Mediterranean-Style Diet for the Primary and Secondary Prevention of Cardiovascular Disease: A Cochrane Review. Glob. Heart 2020, 15, 56. [CrossRef]

47. Grosso, G.; Marventano, S.; Yang, J.; Micek, A.; Pajak, A.; Scalfi, L.; Galvano, F.; Kales, S.N. A comprehensive meta-analysis on evidence of Mediterranean diet and cardiovascular disease: Are individual components equal? Crit. Rev. Food Sci. Nutr. 2017, 57, 3218-3232. [CrossRef]

48. Coltell, O.; Ortega-Azorín, C.; Sorlí, J.V.; Portolés, O.; Asensio, E.M.; Saiz, C.; Barragán, R.; Estruch, R.; Corella, D. Circulating Adiponectin and Its Association with Metabolic Traits and Type 2 Diabetes: Gene-Diet Interactions Focusing on Selected Gene Variants and at the Genome-Wide Level in High-Cardiovascular Risk Mediterranean Subjects. Nutrients 2021, 13, 541. [CrossRef]

49. Barnard, N.D.; Alwarith, J.; Rembert, E.; Brandon, L.; Nguyen, M.; Goergen, A.; Horne, T.; do Nascimento, G.F.; Lakkadi, K.; Tura, A.; et al. A Mediterranean Diet and Low-Fat Vegan Diet to Improve Body Weight and Cardiometabolic Risk Factors: A Randomized, Cross-over Trial. J. Am. Coll. Nutr. 2021, 62, 100060. [CrossRef]

50. Yubero-Serrano, E.M.; Fernandez-Gandara, C.; Garcia-Rios, A.; Rangel-Zuñiga, O.A.; Gutierrez-Mariscal, F.M.; Torres-Peña, J.D.; Marin, C.; Lopez-Moreno, J.; Castaño, J.P.; Delgado-Lista, J.; et al. Mediterranean diet and endothelial function in patients with coronary heart disease: An analysis of the CORDIOPREV randomized controlled trial. PLoS Med. 2020, 17, e1003282. [CrossRef]

51. Chrysohoou, C.; Panagiotakos, D.B.; Pitsavos, C.; Das, U.N.; Stefanadis, C. Adherence to the Mediterranean diet attenuates inflammation and coagulation process in healthy adults: The ATTICA Study. J. Am. Coll. Cardiol. 2004, 44, 152-158. [CrossRef]

52. Dai, J.; Jones, D.P.; Goldberg, J.; Ziegler, T.R.; Bostick, R.M.; Wilson, P.W.; Manatunga, A.K.; Shallenberger, L.; Jones, L.; Vaccarino, V. Association between adherence to the Mediterranean diet and oxidative stress. Am. J. Clin. Nutr. 2008, 88, 1364-1370. [CrossRef]

53. Estruch, R. Anti-inflammatory effects of the Mediterranean diet: The experience of the PREDIMED study. Proc. Nutr. Soc. 2010, 69, 333-340. [CrossRef]

54. Morris, M.C.; Tangney, C.C.; Wang, Y.; Sacks, F.M.; Barnes, L.L.; Bennett, D.A.; Aggarwal, N.T. MIND diet slows cognitive decline with aging. Alzheimers Dement. 2015, 11, 1015-1022. [CrossRef]

55. Berendsen, A.M.; Kang, J.H.; Feskens, E.J.M.; de Groot, C.P.G.M.; Grodstein, F.; van de Rest, O. Association of Long-Term Adherence to the MIND Diet with Cognitive Function and Cognitive Decline in American Women. J. Nutr. Health Aging 2018, 22, 222-229. [CrossRef]

56. Morris, M.C.; Tangney, C.C.; Wang, Y.; Sacks, F.M.; Bennett, D.A.; Aggarwal, N.T. MIND diet associated with reduced incidence of Alzheimer's disease. Alzheimers Dement. 2015, 11, 1007-1014. [CrossRef]

57. Cherian, L.; Wang, Y.; Fakuda, K.; Leurgans, S.; Aggarwal, N.; Morris, M. Mediterranean-Dash Intervention for Neurodegenerative Delay (MIND) Diet Slows Cognitive Decline After Stroke. J. Prev. Alzheimers Dis. 2019, 6, 267-273. [CrossRef] [PubMed]

58. Samieri, C.; Féart, C.; Proust-Lima, C.; Peuchant, E.; Tzourio, C.; Stapf, C.; Berr, C.; Barberger-Gateau, P. Olive oil consumption, plasma oleic acid, and stroke incidence: The Three-City Study. Neurology 2011, 77, 418-425. [CrossRef] [PubMed]

59. Schwingshackl, L.; Hoffmann, G. Monounsaturated fatty acids, olive oil and health status: A systematic review and meta-analysis of cohort studies. Lipids Health Dis. 2014, 13, 154. [CrossRef]

60. Martínez-González, M.A.; Dominguez, L.J.; Delgado-Rodríguez, M. Olive oil consumption and risk of CHD and/or stroke: A meta-analysis of case-control, cohort and intervention studies. Br. J. Nutr. 2014, 112, 248-259. [CrossRef]

61. Mohagheghi, F.; Bigdeli, M.R.; Rasoulian, B.; Hashemi, P.; Pour, M.R. The neuroprotective effect of olive leaf extract is related to improved blood-brain barrier permeability and brain edema in rat with experimental focal cerebral ischemia. Phytomedicine 2011, 18, 170-175. [CrossRef]

62. Rabiei, Z.; Bigdeli, M.R.; Rasoulian, B.; Ghassempour, A.; Mirzajani, F. The neuroprotection effect of pretreatment with olive leaf extract on brain lipidomics in rat stroke model. Phytomedicine 2012, 19, 940-946. [CrossRef]

63. Zamani, M.; Hassanshahi, J.; Soleimani, M.; Zamani, F. Neuroprotective effect of olive oil in the hippocampus CA1 neurons following ischemia: Reperfusion in mice. J. Neurosci. Rural Pract. 2013, 4, 164-170. [CrossRef]

64. Vargas-Molina, S.; Petro, J.L.; Romance, R.; Kreider, R.B.; Schoenfeld, B.J.; Bonilla, D.A.; Benítez-Porres, J. Effects of a ketogenic diet on body composition and strength in trained women. J. Int. Soc. Sports Nutr. 2020, 17, 19. [CrossRef]

65. Takeuchi, F.; Nishikata, N.; Nishimura, M.; Nagao, K.; Kawamura, M. Leucine-Enriched Essential Amino Acids Enhance the Antiseizure Effects of the Ketogenic Diet in Rats. Front. Neurosci. 2021, 15, 225. [CrossRef]

66. Arora, N.; Mehta, T.R. Role of the ketogenic diet in acute neurological diseases. Clin. Neurol. Neurosurg. 2020, $192,105727$. [CrossRef]

67. Maalouf, M.; Sullivan, P.G.; Davis, L.; Kim, D.Y.; Rho, J.M. Ketones inhibit mitochondrial production of reactive oxygen species production following glutamate excitotoxicity by increasing NADH oxidation. Neuroscience 2007, 145, 256-264. [CrossRef] [PubMed] 
68. Cheng, B.; Yang, X.; An, L.; Gao, B.; Liu, X.; Liu, S. Ketogenic diet protects dopaminergic neurons against 6-OHDA neurotoxicity via up-regulating glutathione in a rat model of Parkinson's disease. Brain Res. 2009, 1286, 25-31. [CrossRef]

69. Julio-Amilpas, A.; Montiel, T.; Soto-Tinoco, E.; Gerónimo-Olvera, C.; Massieu, L. Protection of hypoglycemia-induced neuronal death by $\beta$-hydroxybutyrate involves the preservation of energy levels and decreased production of reactive oxygen species. J. Cereb. Blood Flow Metab. 2015, 35, 851-860. [CrossRef]

70. Suzuki, M.; Sato, K.; Dohi, S.; Sato, T.; Matsuura, A.; Hiraide, A. Effect of beta-hydroxybutyrate, a cerebral function improving agent, on cerebral hypoxia, anoxia and ischemia in mice and rats. Jpn. J. Pharm. 2001, 87, 143-150. [CrossRef] [PubMed]

71. Suzuki, M.; Kitamura, Y.; Mori, S.; Sato, K.; Dohi, S.; Sato, T.; Matsuura, A.; Hiraide, A. Beta-hydroxybutyrate, a cerebral function improving agent, protects rat brain against ischemic damage caused by permanent and transient focal cerebral ischemia. Jpn. J. Pharm. 2002, 89, 36-43. [CrossRef]

72. Yang, Q.; Guo, M.; Wang, X.; Zhao, Y.; Zhao, Q.; Ding, H.; Dong, Q.; Cui, M. Ischemic preconditioning with a ketogenic diet improves brain ischemic tolerance through increased extracellular adenosine levels and hypoxia-inducible factors. Brain Res. 2017, 1667, 11-18. [CrossRef]

73. Shaafi, S.; Sharifi-Bonab, M.; Ghaemian, N.; Mokhtarkhani, M.; Akbari, H. Early Motor-Behavioral Outcome of Ischemic Stroke with Ketogenic Diet Preconditioning: Interventional Animal Study. J. Stroke Cereb. Dis. 2019, 28, 1032-1039. [CrossRef] [PubMed]

74. Han, P.; Zhang, W.; Kang, L.; Ma, Y.; Fu, L.; Jia, L.; Yu, H.; Chen, X.; Hou, L.; Wang, L.; et al. Clinical Evidence of Exercise Benefits for Stroke. Adv. Exp. Med. Biol. 2017, 1000, 131-151. [CrossRef]

75. Diekmann, R.; Wojzischke, J. The role of nutrition in geriatric rehabilitation. Curr. Opin. Clin. Nutr. Metab. Care 2018, 21, 14-18. [CrossRef] [PubMed]

76. Kokura, Y.; Maeda, K.; Wakabayashi, H.; Nishioka, S.; Higashi, S. High Nutritional-Related Risk on Admission Predicts Less Improvement of Functional Independence Measure in Geriatric Stroke Patients: A Retrospective Cohort Study. J. Stroke Cereb. Dis. 2016, 25, 1335-1341. [CrossRef]

77. Nishioka, S.; Wakabayashi, H.; Nishioka, E.; Yoshida, T.; Mori, N.; Watanabe, R. Nutritional Improvement Correlates with Recovery of Activities of Daily Living among Malnourished Elderly Stroke Patients in the Convalescent Stage: A Cross-Sectional Study. J. Acad. Nutr. Diet. 2016, 116, 837-843. [CrossRef] [PubMed]

78. Shimazu, S.; Yoshimura, Y.; Kudo, M.; Nagano, F.; Bise, T.; Shiraishi, A.; Sunahara, T. Frequent and personalized nutritional support leads to improved nutritional status, activities of daily living, and dysphagia after stroke. Nutrition 2021, 83, 111091. [CrossRef]

79. Nishioka, S.; Wakabayashi, H.; Yoshida, T.; Mori, N.; Watanabe, R.; Nishioka, E. Obese Japanese Patients with Stroke Have Higher Functional Recovery in Convalescent Rehabilitation Wards: A Retrospective Cohort Study. J. Stroke Cereb. Dis. 2016, 25, 26-33. [CrossRef]

80. Burke, D.T.; Al-Adawi, S.; Bell, R.B.; Easley, K.; Chen, S.; Burke, D.P. Effect of body mass index on stroke rehabilitation. Arch. Phys. Med. Rehabil. 2014, 95, 1055-1059. [CrossRef]

81. Rabadi, M.H.; Coar, P.L.; Lukin, M.; Lesser, M.; Blass, J.P. Intensive nutritional supplements can improve outcomes in stroke rehabilitation. Neurology 2008, 71, 1856-1861. [CrossRef] [PubMed]

82. Ramasamy, D.K.; Dutta, T.; Kannan, V.; Chandramouleeswaran, V. Amino acids in post-stroke rehabilitation. Nutr. Neurosci. 2021, 24, 426-431. [CrossRef] [PubMed]

83. Aquilani, R.; Boselli, M.; D'Antona, G.; Baiardi, P.; Boschi, F.; Viglio, S.; Iadarola, P.; Pasini, E.; Barbieri, A.; Dossena, M.; et al. Unaffected arm muscle hypercatabolism in dysphagic subacute stroke patients: The effects of essential amino acid supplementation. BioMed Res. Int. 2014, 2014, 964365. [CrossRef]

84. Ikeda, T.; Morotomi, N.; Kamono, A.; Ishimoto, S.; Miyazawa, R.; Kometani, S.; Sako, R.; Kaneko, N.; Iida, M.; Kawate, N. The Effects of Timing of a Leucine-Enriched Amino Acid Supplement on Body Composition and Physical Function in Stroke Patients: A Randomized Controlled Trial. Nutrients 2020, 12, 1928. [CrossRef] [PubMed]

85. Sari, A.; Durmus, B.; Karaman, C.A.; Ogut, E.; Aktas, I. A randomized, double-blind study to assess if vitamin D treatment affects the outcomes of rehabilitation and balance in hemiplegic patients. J. Phys. Ther. Sci. 2018, 30, 874-878. [CrossRef]

86. Gupta, A.; Prabhakar, S.; Modi, M.; Bhadada, S.K.; Kalaivani, M.; Lal, V.; Khurana, D. Effect of Vitamin D and calcium supplementation on ischaemic stroke outcome: A randomised controlled open-label trial. Int. J. Clin. Pract. 2016, 70, 764-770. [CrossRef]

87. Siotto, M.; Santoro, M.; Aprile, I. Vitamin D and Rehabilitation after Stroke: Status of Art. Appl. Sci. 2020, 10, 1973. [CrossRef]

88. Utkan Karasu, A.; KarataŞ, G.K. Effect of Vitamin D Supplementation on Lower Extremity Motor Function and Ambulation in Stroke Patients. Turk. J. Med. Sci. 2021, 51, 1413-1419. [CrossRef]

89. Momosaki, R.; Abo, M.; Urashima, M. Vitamin D Supplementation and Post-Stroke Rehabilitation: A Randomized, Double-Blind, Placebo-Controlled Trial. Nutrients 2019, 11, 1295. [CrossRef]

90. Hannan, M.A.; Dash, R.; Haque, M.N.; Mohibbullah, M.; Sohag, A.A.M.; Rahman, M.A.; Uddin, M.J.; Alam, M.; Moon, I.S. Neuroprotective Potentials of Marine Algae and Their Bioactive Metabolites: Pharmacological Insights and Therapeutic Advances. Mar. Drugs 2020, 18, 347. [CrossRef]

91. Hu, L.; Chen, W.; Tian, F.; Yuan, C.; Wang, H.; Yue, H. Neuroprotective role of fucoxanthin against cerebral ischemic/reperfusion injury through activation of Nrf2/HO-1 signaling. Biomed. Pharm. 2018, 106, 1484-1489. [CrossRef] [PubMed] 
92. Pangestuti, R.; Vo, T.S.; Ngo, D.H.; Kim, S.K. Fucoxanthin ameliorates inflammation and oxidative reponses in microglia. J. Agric. Food Chem. 2013, 61, 3876-3883. [CrossRef] [PubMed]

93. Zhou, L.; Zhang, J.; Wang, C.; Sun, Q. Tanshinone inhibits neuronal cell apoptosis and inflammatory response in cerebral infarction rat model. Int. J. Immunopathol. Pharm. 2017, 30, 123-129. [CrossRef]

94. Lin, J.; Huang, L.; Yu, J.; Xiang, S.; Wang, J.; Zhang, J.; Yan, X.; Cui, W.; He, S.; Wang, Q. Fucoxanthin, a Marine Carotenoid, Reverses Scopolamine-Induced Cognitive Impairments in Mice and Inhibits Acetylcholinesterase in Vitro. Mar. Drugs 2016, 14, 67. [CrossRef]

95. Wu, S.; Yue, Y.; Tian, H.; Tao, L.; Wang, Y.; Xiang, J.; Wang, S.; Ding, H. Tramiprosate protects neurons against ischemic stroke by disrupting the interaction between PSD95 and nNOS. Neuropharmacology 2014, 83, 107-117. [CrossRef]

96. Kim, J.H.; Lee, N.S.; Jeong, Y.G.; Lee, J.H.; Kim, E.J.; Han, S.Y. Protective efficacy of an Ecklonia cava extract used to treat transient focal ischemia of the rat brain. Anat. Cell Biol. 2012, 45, 103-113. [CrossRef]

97. Cui, Y.; Amarsanaa, K.; Lee, J.H.; Rhim, J.K.; Kwon, J.M.; Kim, S.H.; Park, J.M.; Jung, S.C.; Eun, S.Y. Neuroprotective mechanisms of dieckol against glutamate toxicity through reactive oxygen species scavenging and nuclear factor-like 2/heme oxygenase-1 pathway. Korean J. Physiol Pharm. 2019, 23, 121-130. [CrossRef]

98. Zhao, D.; Kwon, S.H.; Chun, Y.S.; Gu, M.Y.; Yang, H.O. Anti-Neuroinflammatory Effects of Fucoxanthin via Inhibition of Akt/NF$\kappa \mathrm{B}$ and MAPKs / AP-1 Pathways and Activation of PKA/CREB Pathway in Lipopolysaccharide-Activated BV-2 Microglial Cells. Neurochem. Res. 2017, 42, 667-677. [CrossRef] 